\title{
Infus Desain Notifikasi Dengan Aplikasi Media Sosial Berbasis Internet of Things (IOT)
}

\author{
Haldina Syahfitri Azhari Lubis ${ }^{* 1}$, Ibnu Rasyid Munthe ${ }^{2}$, Rahmadani Pane ${ }^{3}$ \\ ${ }_{1,2,3}$ Universitas Labuhan Batu, Rantau Prapat, Indonesia \\ Email : $\underline{\text { haldinalubis120@gmail.com }}{ }^{* 1}, \underline{\text { ibnurasyidmunthe@gmail.com }}^{2}$
}

\begin{abstract}
Abstrak
Penelitian ini membahas tentang alat pendeteksi infus di sebuah ruangan rumah sakit. Alat ini dirancang untuk membantu perawat rumah sakit untuk mengatasi lebih cepat untuk menghindari masalah akibat pemasangan infus. Sensor load cell digunakan sebagai pendeteksi berat yang mengirimkan notifikasi kepada perawat melalui aplikasi telegram yang telah terpasang. Perawat akan mendapatkan pesan notifikasi yang dikirimkan ke telegram jika sensor telah membaca berat badan. Alat ini dibuat menggunakan sensor load cell dan NodeMCUWi-FiESP866 yang berfungsi untuk mengirimkan notifikasi hasil input data sensor ke platform Internet of Things (IOT) yaitu Telegram. Perawat perlu terkoneksi dengan jaringan internet untuk mendapatkan notifikasi di telegram. Hasil pengujian menunjukkan bahwa waktu yang dibutuhkan untuk mengirim dan menerima notifikasi di Telegram membutuhkan waktu sekitar 2-5 detik. Pesan akan dikirim 3 kali, pertama infus WARNING hampir habis (waspada), kedua WARNING infus hampir habis (standby) dan WARNING infus hampir habis (silahkan ganti). Jika infus tidak diganti oleh perawat, akan diperingatkan oleh Buzzer. Namun, waktu dapat dipengaruhi oleh konektivitas jaringan internet yang tersedia. Namun, waktu dapat dipengaruhi oleh jaringan internet yang tersedia.
\end{abstract}

Kata kunci : Telegram, Arduino R3, Sel Muat, NodeMCU ESP8266

\begin{abstract}
This study discusses an infusion detector in a hospital room. This tool is designed to help hospital nurses to cope more quickly to avoid problems due to infusion. The load cell sensor is used as a weight detector that sends notifications to nurses via the telegram application that has been installed. The nurse will get a message notification sent to the telegram if the sensor has read the weight. This tool is made using a load cell sensor and NodeMCUWi-FiESP866 which functions to send notifications of sensor data input results to the Internet of Things (IOT) platform, namely Telegram. Nurses need to be connected to the internet network to get notifications on telegram. The test results show that the time it takes to send and receive notifications on Telegram takes about 2-5 seconds. Messages will be sent 3 times, the first is the WARNING infusion is running low (alert), the second is the WARNING infusion is running low (standby) and the WARNING infusion is almost exhausted (please change). If the infusion is not changed by the nurse, a buzzer will be warned. However, the time may be affected by the available internet network connectivity. However, the time may be affected by the available internet network.
\end{abstract}

Keywords : Telegram, Arduino R3, Load Cell, NodeMCU ESP8266

\section{PENDAHULAUAN}

Cairan intravena adalah pemberian sejumlah cairan ke dalam tubuh, melalui jarum ke pembuluh darah. Tujuan pemberian infus pada pasien adalah untuk mengganti cairan tubuh dan mengkompensasi jumlah elektrolit yang masuk ke dalam tubuh, dapat diberikan dengan maksud menambah kalori, Sebagai obat, diberikan dalam jumlah banyak dan terus menerus bila tidak dapat disuntikkan secara normal, misalnya obat antikanker, antibiotik, anestesi, hormon yang larut dalam air dan vitamin. Tindakan ini dilakukan untuk memenuhi kebutuhan cairan dan elektrolit serta sebagai tindakan pengobatan dan pemberian makan (NUR, 2016). Penelitian tentang monitoring infus telah dilakukan oleh (Erdisna, 2014), menggunakan mikrokontroler ATmega8535 untuk mengontrol pompa Infus, kemudian dalam penelitian (Nataliana et al.

2016) menggunakan mikrokontroler yang sama dapat memantau penerimaan pasien rawat inap dengan menggunakan sensor led infra merah dan Photodiode. 
Selanjutnya penelitian tentang monitoring infus sedang berkembang menuju internet of things (IOT) seperti penelitian (Sasmoko\& Wicaksono, 2017) menggunakan sensor Load Cell dan modul Wi-Fi Esp8266 dapat mengirimkan informasi melalui web tetesan infus dengan margin error dari 2,4\% transmisi data. Selanjutnya (Yunardi et al., 2018) dengan menggunakan teknologi telemetri dan aplikasi LabVIEW diperoleh tingkat keberhasilan sebesar 96,7\%.

Penggunaan smartphone untuk notifikasi tetesan infus dan monitoring juga dilakukan dalam penelitian (Aziis, 2018). Terjadi kesalahan dalam proses pengiriman data dan sensor lampu baca, dalam penelitian (Yudhana \& Putra, 2018), monitoring menggunakan smartphone Android mengalami kendala karena komunikasi menggunakan Bluetooth Hc-06 yang jangkauan maksimal 10 meter. Dalam sebuah penelitian (Anwar \& Ibadillah, 2018) Menggunakan Photodiode dan LED untuk pendeteksian droplet, dan sensor Load Cell untuk sisa cairan infus, menggunakan modul Wi-Fi Esp8266, error 0,59\%, sisa cairan $0,83 \%$ dalam waktu 30 detik pengiriman. Mengontrol perangkat yang memanfaatkan teknologi internet dengan menggunakan aplikasi media sosial telegram (Candra et al., 2019). Menggunakan NodeMCU ESP8266 (Ilham et al., 2019). Dari penelitian sebelumnya, al., 2018) desain infus monitoring menggunakan arduino dan web memiliki akurasi 95\%, sensor LDR 90\% (Zufa, 2020).

\section{TINJAUAN LITERATUR}

Terapi intravena adalah menempatkan cairan steril melalui jarum langsung ke pembuluh darah pasien. Biasanya cairan steril mengandung elektrolit (natrium, kalsium, kalium), nutrisi, vitamin atau obat-obatan. Infus cairan intravena adalah pemberian sejumlah cairan ke dalam tubuh, melalui jarum, ke dalam vena untuk menggantikan cairan atau nutrisi yang hilang dari tubuh. Terapi intravena adalah menempatkan cairan steril melalui jarum langsung ke pembuluh darah pasien. Biasanya cairan steril mengandung elektrolit (natrium, kalsium, kalium), nutrisi vitamin atau obat-obatan (Nur et al., 2015).

Memasang infus adalah memasukkan cairan atau obat-obatan langsung ke pembuluh darah vena dalam jumlah banyak dan dalam waktu lama dengan menggunakan infus set. Terapi intravena (IV) digunakan untuk memberikan cairan ketika pasien tidak dapat menelan, tidak sadar, dehidrasi atau syok, untuk memberikan garam yang dibutuhkan untuk menjaga keseimbangan elektrolit, atau glukosa yang dibutuhkan untuk metabolisme dan untuk memberikan obat-obatan.

\section{METODE PENELITIAN}

Alat dan bahan yang kami gunakan dalam merancang perangkat peringatan infus berbasis mikrokontroler untuk pasien terdiri dari perangkat keras dan perangkat lunak, antara lain:

\subsection{Perangkat keras}

Persyaratan peralatan yang digunakan dalam perancangan perangkat peringatan input meliputi:

Tabel 1. Spesifikasi Perangkat Keras

\begin{tabular}{|l|l|l|}
\hline No & Nama & \multicolumn{1}{|c|}{ Fungsi } \\
\hline 1 & Arduino Uno R3 & $\begin{array}{l}\text { Pengontrol dalam desain perangkat peringatan } \\
\text { infus. }\end{array}$ \\
\hline 2 & $\begin{array}{l}\text { ESP8266 MCU } \\
\text { Modul Node }\end{array}$ & $\begin{array}{l}\text { Hubungkan data yang dihasilkan oleh } \\
\text { mikrokontroler melalui Aplikasi Telegram }\end{array}$ \\
\hline 3 & modul HX711 & $\begin{array}{l}\text { Untuk memprogram HX711, Arduino } \\
\text { membutuhkan tambahan perpustakaan, yaitu } \\
\text { perpustakaan HX711 }\end{array}$ \\
\hline 4 & $\begin{array}{l}\text { Sensor sel beban } \\
\text { cell }\end{array}$ & $\begin{array}{l}\text { Sensor sel beban terdiri dari 4 konektor yang } \\
\text { terhubung ke modul HX711 yang berfungsi sebagai } \\
\text { pendeteksi berat badan untuk infus. }\end{array}$ \\
\hline 5 & Bel & $\begin{array}{l}\text { Rangkaian buzzer atau yang sering disebut } \\
\text { rangkaian alarm pengingat pesan dan peringatan, }\end{array}$ \\
\hline 6 & Peloncat & Hubungkan seluruh alat. \\
\hline 7 & transistor NPN & penguat, pengontrol, penyearah, osilator, modulator \\
\hline
\end{tabular}




\subsection{Perangkat lunak} adalah:

Perangkat lunak yang digunakan dalam perancangan infusion warning berbasis mikrokontroler

Tabel 2. Persyaratan Perangkat Lunak

\begin{tabular}{|l|l|l|}
\hline No & \multicolumn{1}{|c|}{ Nama } & \multicolumn{1}{c|}{ Fungsi } \\
\hline 1 & Arduino IDE & $\begin{array}{l}\text { Digunakan untuk mengunggah program peringatan } \\
\text { infus rendah ke }\end{array}$ \\
\hline & & papan Arduino. \\
\hline 2 & Proteus & Digunakan untuk mensimulasikan sirkuit \\
\hline 3 & Fritzing & $\begin{array}{l}\text { Digunakan untuk merancang skema sirkuit dan } \\
\text { elektronik }\end{array}$ \\
\hline 4 & Microsoft Visio & Digunakan untuk merancang gambar, skema \\
\hline
\end{tabular}

\section{Prosedur kerja}

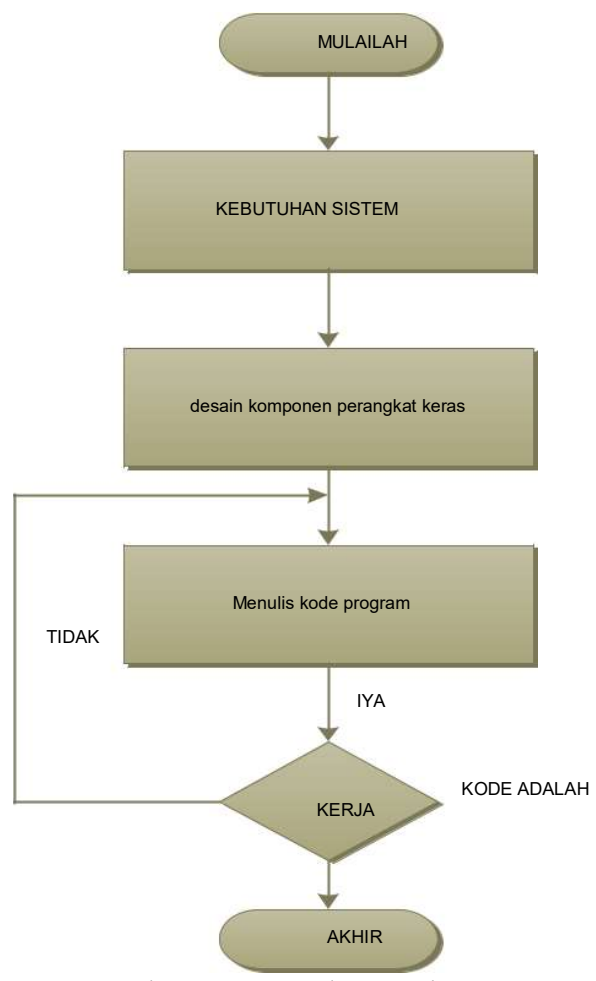

Gambar 1. Prosedur Kerja

\subsection{Perencanaan sistem}

Perancangan ini dibuat untuk mempermudah proses perancangan alat peringatan infus menggunakan sensor load cell berbasis mikrokontroler. Rangkaian alat peringatan habis infus ini terdiri dari 3 bagian yaitu bagian input, bagian kontrol, bagian output, terlihat pada Gambar 2.

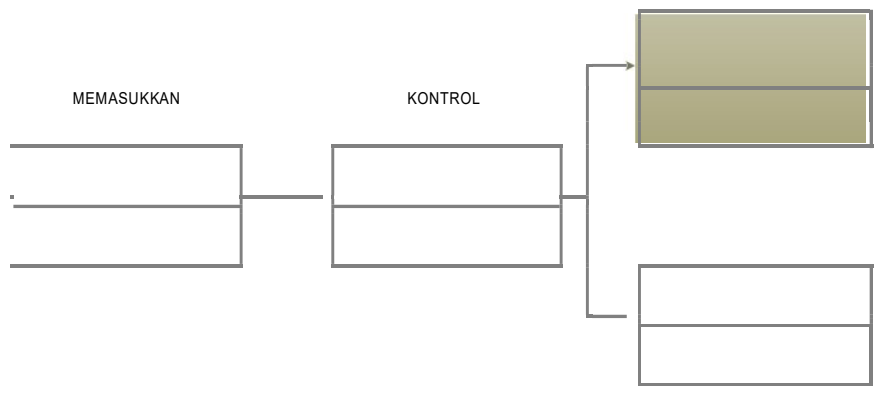


Gambar 2. Desain Sistem

Dari Gambar 2 terlihat bahwa terdapat 3 bagian rangkaian yaitu bagian input, bagian ini terdiri dari sensor load cell yang berfungsi memberikan nilai input pada tingkat intensitas berat yang menentukan kondisi infus.

Bagian kontrol, sistem kontrol sistem peringatan infus menggunakan Arduino yang berfungsi untuk menerima input dari sensor load cell kemudian memberikan perintah ke modul HX711 yang merupakan penerjemah mengubah perubahan terukur perubahan resistansi dan mengubahnya menjadi besaran tegangan dan berat melalui sirkuit yang ada, dan kemudian Hx711 memberi tahu modul Wi-Fi NodeMCU bahwa saya harus mengganti bobot IV, dan kemudian outputnya dikirim ke telegram dan buzzer.

Bagian keluaran yang merupakan hasil terakhir dari rangkaian alat peringatan infus ini memiliki dua keluaran yaitu ke aplikasi telegram berupa pesan bahwa infus hampir habis dan harus diganti. Dan output lainnya adalah buzzer yaitu suara yang dikeluarkan jika perawat tidak mengganti infus jika sudah diperingatkan 3 kali via telegram tadi.

\subsection{Prinsip Kerja Alat}

Berikut ini adalah flowchart rancangan cara kerja alat peringatan infus. Pada Gambar 3 terdapat rangkaian Flowchart program peringatan infus habis untuk pasien berbasis mikrokontroler dimana program dimulai dari awal kemudian sumbernya akan dipasang oleh sensor load cell, program yang akan mendeteksi berat infus, dan jika berat infus telah mencapai $137 \mathrm{~g}-140 \mathrm{~g}$.

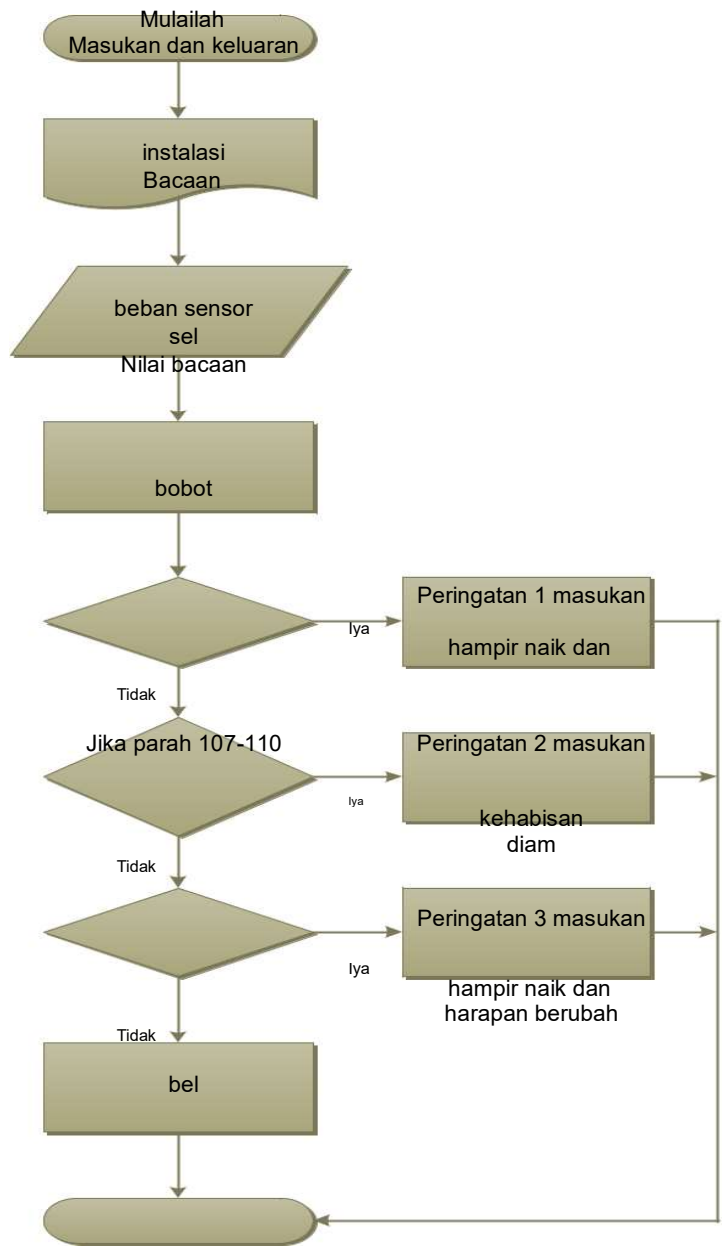


Gambar 3 Prinsip kerja alat

Akan diberitahukan kepada perawat melalui aplikasi telegram berupa pesan, untuk segera mengganti infus baru. Dan jika perawat tidak mengganti infus baru akan diberikan peringatan kedua jika berat infus telah mencapai $107-110 \mathrm{~g}$, dan yang terakhir jika tidak diganti akan diberikan peringatan ketiga ketika berat telah mencapai $77-80 \mathrm{~g}$. dan juga akan diingatkan dengan alarm suara.

\subsection{Seperangkat alat}

Dengan menggunakan aplikasi Fritzing didapatkan desain alat sebagai berikut, Peringatan keluar infus ini bekerja berdasarkan input load cell yang akan membaca bobot, kemudian modul HX711 akan mengolah data tersebut, kemudian dinotifikasikan ke NodeMCUESP8266 dan dikendalikan oleh Arduino, yang kemudian Node MCU diberikan notifikasi melalui aplikasi telegram dan buzzer.

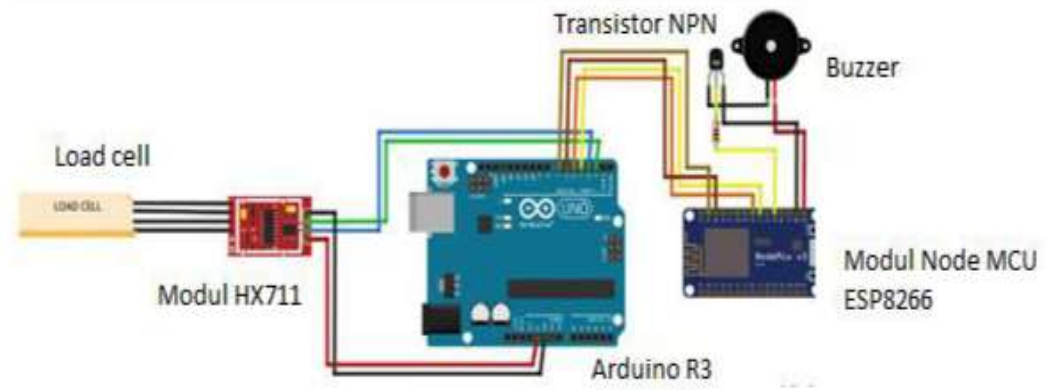

Gambar 4 Skema Alat

\subsection{Bot Telegram}

Penulis perlu membuat bot pada telegram agar sensor Load cell dapat mengirimkan notifikasi ke telegram. Membuat bot telegram penulis memerlukan token pengguna yang dapat ditulis yang dapat dipertanggungjawabkan @BotFather dan ID Pengguna yang penulis dapatkan dari akun@get_id.

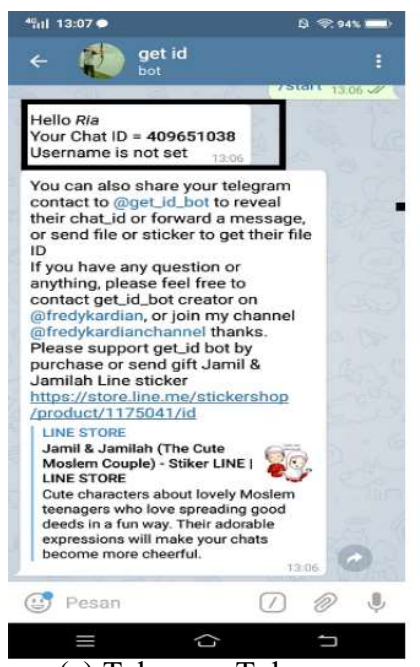

(a) Telegram Token

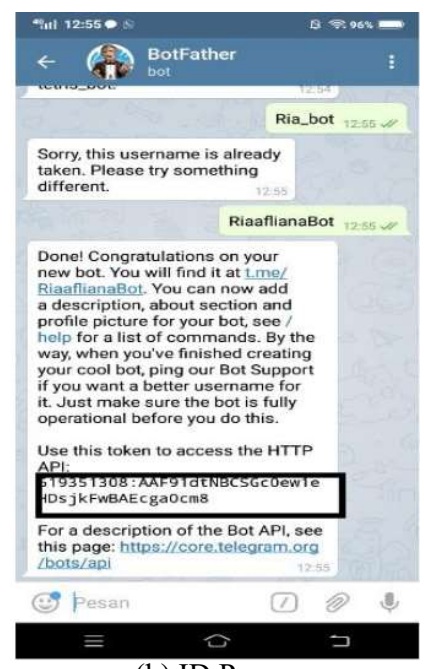

(b) ID Pengguna

Gambar 5 (a) dan (b) Desain BOT Telegram

\section{HASIL DAN PEMBAHASAN}

Infusion warning berbasis mikrokontroler bekerja dimana infus yang diinput akan diterima oleh Arduino sebagai pengontrol sistem, memberikan perintah pada modul HX711 sebagai penghubung antara Arduino dengan modul Wi-Fi Node MCU dengan output berupa pesan telegram dan Bel. 


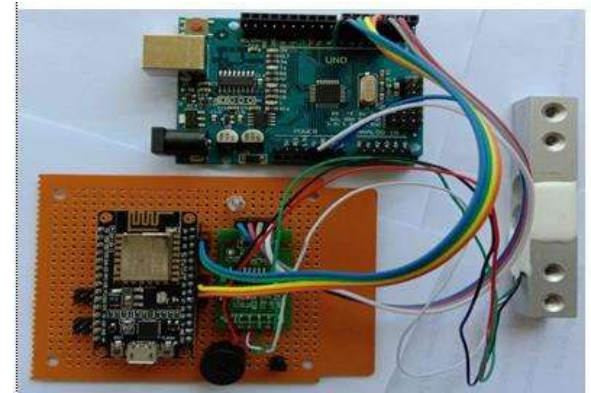

Prosedur Pengujian

Gambar 6. Perangkat Keseluruhan Overall

\section{Pengujian Alat Keseluruhan}

Untuk menjalankan alat peringatan infus keluar berbasis mikrokontroler adalah sebagai berikut:

a) Hal pertama yang harus dilakukan adalah merakit semua alat bersama-sama dan siap untuk dijalankan

b) Setelah semuanya terhubung, letakkan infus di sensor load cell yang merupakan sumber input utama.

c) Setelah load cell membaca berat infus, berat akan diubah menjadi data analog oleh Modul HX711.

d) Kemudian jika data sudah menjadi data digital dan dikendalikan oleh Arduino, maka telegram dan buzzer akan dikirimkan melalui NodeMCUESP8266.

\section{Hasil tes}

\section{Telegram}

Saat status infus pada serial monitor menyatakan normal ( $>180 \mathrm{~g})$, infus masih banyak, dan saat status berubah menjadi alert maka otomatis notifikasi masuk ke dalam ketel, seperti yang dapat kita lihat pada Gambar 4. Begitu juga jika status pada serial monitor telah berubah menjadi standby, maka secara otomatis akan diberitahukan kembali bahwa infus dalam keadaan standby. Dan saat infus hampir habis di serial monitor akan mengirimkan notifikasi ke telegram secara otomatis juga, dan ketika infus sudah masuk silahkan ganti, delay 7 detik sampai buzzer berbunyi 10 detik terus habis.

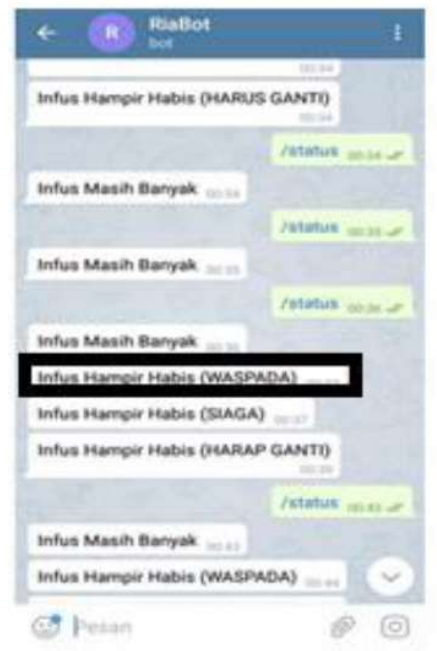

(a) Peringatan Peringatan

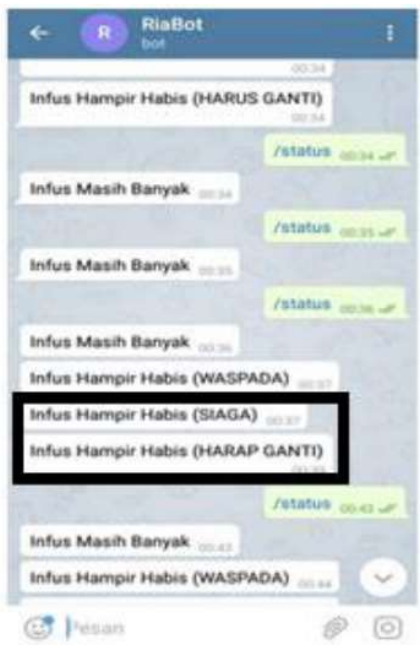

(b) Peringatan Menganggur

Gambar 7.(a) dan (b) Notifikasi Via Telegram

Tabel 3. Data Uji Infus

\begin{tabular}{|l|c|c|c|}
\hline No & Status Infus & $\begin{array}{c}\text { Pemberitahuan } \\
(\mathrm{y} / \mathrm{t})\end{array}$ & Waktu \\
\hline
\end{tabular}




\begin{tabular}{|c|c|c|c|}
\hline 1 & $\begin{array}{l}\text { Infusnya masih banyak } \\
(>190 \mathrm{~g})\end{array}$ & $\mathrm{Y}$ & 3 detik \\
\hline 2 & $\begin{array}{l}\text { Infus hampir habis } \\
\text { (Peringatan) }\end{array}$ & $\mathrm{Y}$ & 4 detik \\
\hline 3 & Infus rendah (siaga) & $\mathrm{Y}$ & 3 detik \\
\hline 4 & $\begin{array}{l}\text { Infusnya rendah } \\
\text { (mohon ganti) }\end{array}$ & $\mathrm{Y}$ & 2 detik \\
\hline 5 & $\begin{array}{l}\text { Infusnya masih banyak } \\
(>189 \mathrm{~g})\end{array}$ & $\mathrm{Y}$ & 3 detik \\
\hline 6 & $\begin{array}{l}\text { Infus hampir habis } \\
\text { (Peringatan) }\end{array}$ & $\mathrm{Y}$ & 3 detik \\
\hline 7 & Infus rendah (siaga) & $\mathrm{Y}$ & 5 detik \\
\hline 8 & $\begin{array}{l}\text { Infusnya rendah } \\
\text { (mohon ganti) }\end{array}$ & $\mathrm{Y}$ & 3 detik \\
\hline 9 & $\begin{array}{l}\text { Infusnya masih banyak } \\
(>187 \mathrm{~g})\end{array}$ & $\mathrm{Y}$ & 3 detik \\
\hline 10 & $\begin{array}{l}\text { Infus hampir habis } \\
\text { (Peringatan) }\end{array}$ & $\mathrm{Y}$ & 4 detik \\
\hline 11 & Infus rendah (siaga) & $\mathrm{Y}$ & 4 detik \\
\hline 12 & $\begin{array}{l}\text { Infusnya rendah } \\
\text { (mohon ganti) }\end{array}$ & $\mathrm{Y}$ & 3 detik \\
\hline 13 & $\begin{array}{l}\text { Infusnya masih banyak } \\
(>180 \mathrm{~g})\end{array}$ & $\mathrm{Y}$ & 4 detik \\
\hline 14 & $\begin{array}{l}\text { Infus hampir habis } \\
\text { (Peringatan) }\end{array}$ & $\mathrm{Y}$ & 4 detik \\
\hline 15 & Infus rendah (siaga) & $\mathrm{Y}$ & 1 detik \\
\hline 16 & $\begin{array}{l}\text { Infusnya rendah } \\
\text { (mohon ganti) }\end{array}$ & $\mathrm{Y}$ & 2 detik \\
\hline
\end{tabular}

Dari tabel 3 menunjukkan hasil pengujian notifikasi telegram bahwa pesan yang masuk ke telegram berhasil ketika load cell membaca dengan berat hingga mengirimkan notifikasi ke telegram, dan dapat berfungsi sesuai keinginan. Sistem yang digunakan harus terkoneksi dengan Jaringan internet, proses pengiriman data tergantung pada kekuatan sinyal hotspot atau Wi-Fi. Jika sensor telah membaca bobot 94g maka status akan berubah menjadi standby dan bobot tertera pada serial monitor juga sesuai dengan keadaan faktual, seperti terlihat pada Gambar 8 yang menunjukkan bobot yang dibaca oleh sensor load cell. Serial monitor Node MCU yang ditampilkan jika beratnya 94g akan menunjukkan status alert, sehingga pengujian ini membuktikan bahwa output yang dihasilkan oleh load cell sudah sesuai, seperti yang dapat kita lihat pada Gambar 8.

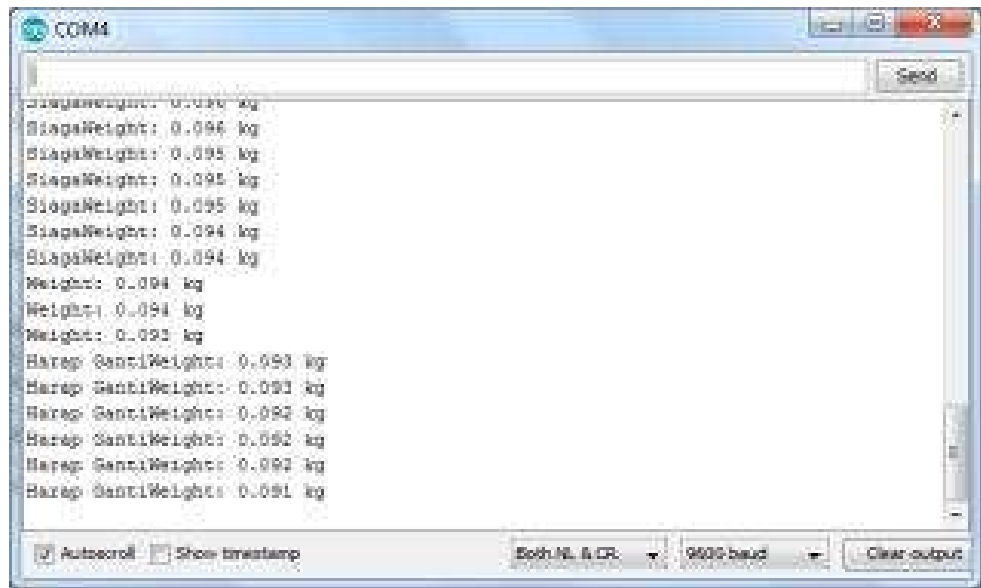

Gambar 8. Alat Pengujian pada Serial Monitor 
Jurnal Teknik Informatika Unika St. Thomas (JTIUST), Volume 06 Nomor 01, Juni 2021, ISSN: 2548-1916, e-ISSN: 2657-1501

\begin{tabular}{|c|c|c|c|c|}
\hline No & Berat Faktual & Berat Sistem & Kesalahan & NRata-rata ${ }^{2}$ \\
\hline 1 & $53 \mathrm{~g}$ & $53 \mathrm{~g}$ & 0 & 0 \\
\hline 2 & $181 \mathrm{~g}$ & $181 \mathrm{~g}$ & 0 & 0 \\
\hline 3 & $81 \mathrm{~g}$ & $81 \mathrm{~g}$ & 0 & 0 \\
\hline 4 & $129 \mathrm{~g}$ & $129 \mathrm{~g}$ & 0 & 0 \\
\hline 5 & $37 \mathrm{~g}$ & $37 \mathrm{~g}$ & 0 & 0 \\
\hline 6 & $22 \mathrm{~g}$ & $22 \mathrm{~g}$ & 0 & 0 \\
\hline 7 & $177 \mathrm{~g}$ & $177 \mathrm{~g}$ & 0 & 0 \\
\hline 8 & $103 \mathrm{~g}$ & $103 \mathrm{~g}$ & 0 & 0 \\
\hline 9 & $80 \mathrm{~g}$ & $80 \mathrm{~g}$ & 0 & 0 \\
\hline 10 & $43 \mathrm{~g}$ & $43 \mathrm{~g}$ & 0 & 0 \\
\hline 11 & $14 \mathrm{~g}$ & $14 \mathrm{~g}$ & 0 & 0 \\
\hline 12 & $16 \mathrm{~g}$ & $16 \mathrm{~g}$ & 0 & 0 \\
\hline 13 & $82 \mathrm{~g}$ & $82 \mathrm{~g}$ & 0 & 0 \\
\hline 14 & $21 \mathrm{~g}$ & $21 \mathrm{~g}$ & 0 & 0 \\
\hline 15 & $15 \mathrm{~g}$ & $15 \mathrm{~g}$ & 0 & 0 \\
\hline 16 & $57 \mathrm{~g}$ & $57 \mathrm{~g}$ & 0 & 0 \\
\hline 17 & $16 \mathrm{~g}$ & $16 \mathrm{~g}$ & 0 & 0 \\
\hline 18 & $47 \mathrm{~g}$ & $47 \mathrm{~g}$ & 0 & 0 \\
\hline 19 & $17 \mathrm{~g}$ & $17 \mathrm{~g}$ & 0 & 0 \\
\hline 20 & $6 \mathrm{~g}$ & $6 g$ & 0 & 0 \\
\hline 21 & $17 \mathrm{~g}$ & $17 \mathrm{~g}$ & 0 & 0 \\
\hline 22 & $21 \mathrm{~g}$ & $21 \mathrm{~g}$ & 0 & 0 \\
\hline 23 & $12 \mathrm{~g}$ & $12 \mathrm{~g}$ & 0 & 0 \\
\hline 24 & $31 \mathrm{~g}$ & $31 \mathrm{~g}$ & 0 & 0 \\
\hline 25 & $199 \mathrm{~g}$ & $199 \mathrm{~g}$ & 0 & 0 \\
\hline 26 & $61 \mathrm{~g}$ & $61 \mathrm{~g}$ & 0 & 0 \\
\hline 27 & $61 \mathrm{~g}$ & $61 \mathrm{~g}$ & 0 & 0 \\
\hline 28 & $188 \mathrm{~g}$ & $188 \mathrm{~g}$ & 0 & 0 \\
\hline 29 & $79 \mathrm{~g}$ & $79 \mathrm{~g}$ & 0 & 0 \\
\hline 30 & $160 \mathrm{~g}$ & $160 \mathrm{~g}$ & 0 & 0 \\
\hline 31 & $111 \mathrm{~g}$ & $111 \mathrm{~g}$ & 0 & 0 \\
\hline 32 & $102 \mathrm{~g}$ & $102 \mathrm{~g}$ & 0 & 0 \\
\hline 33 & $85 \mathrm{~g}$ & $85 \mathrm{~g}$ & 0 & 0 \\
\hline 34 & $39 \mathrm{~g}$ & $39 \mathrm{~g}$ & 0 & 0 \\
\hline 35 & $84 \mathrm{~g}$ & $84 \mathrm{~g}$ & 0 & 0 \\
\hline 36 & $4 \mathrm{~g}$ & $4 \mathrm{~g}$ & 0 & 0 \\
\hline 37 & $61 \mathrm{~g}$ & $61 \mathrm{~g}$ & 0 & 0 \\
\hline 38 & $45 \mathrm{~g}$ & $45 \mathrm{~g}$ & 0 & 0 \\
\hline 39 & $9 g$ & $9 g$ & 0 & 0 \\
\hline 40 & $15 \mathrm{~g}$ & $15 \mathrm{~g}$ & 0 & 0 \\
\hline
\end{tabular}

\section{DISKUSI}

Pengujian verifikasi dilakukan dengan membandingkan hasil bobot faktual dan bobot sistem, menggunakan rumus Means Square Error (MSE). Tes satu menunjukkan berat 53g dalam status faktual dan menunjukkan status tolong ubah dalam status sistem, yang menunjukkan bahwa sensor sel beban telah berhasil membaca beban. Sedangkan pada pengujian kedua memiliki bobot faktual $181 \mathrm{~g}$ dan menunjukkan status sistem normal, karena bobot yang dibaca oleh load cell sama dengan bobot faktual yang artinya tahap uji verifikasi sistem berhasil, dan begitu seterusnya. Jadi valueMean Square Error (MSE) adalah 0

\section{KESIMPULAN}

Berdasarkan hasil pengujian pada alat peringatan infus habis pakai untuk pasien berbasis mikrokontroler dapat ditarik beberapa kesimpulan: 
Alat akan mengirimkan notifikasi melalui telegram, bila sisa berat cairan infus adalah $137 \mathrm{~g}$ hingga $140 \mathrm{~g}, 107 \mathrm{~g}$ hingga $110 \mathrm{~g}$, dan $77 \mathrm{~g}$ hingga $80 \mathrm{~g}$.Pesan yang dikirimkan melalui telegram terkirim sebanyak 3 kali yaitu PERINGATAN infus hampir habis (Alert), a PERINGATAN infus hampir habis (Standby) dan PERINGATAN infus hampir habis (Mohon ganti). Jika tidak diganti oleh perawat, mereka akan diberi peringkat dengan Buzzer. Dari uji verifikasi berat infus, MSE adalah 0.

\section{DAFTAR PUSTAKA}

[1]. Anwar, HN, \& Ibadillah, AF (2018). Alat Pemantau Kondisi Infus Dengan Internet Of Things (IoT) Berbasis

[2]. Mikrokontroler ATMega16. Jurnal Teknik Elektro Dan Komputer TRIAC, 5(1), 1-5. Aziz, MS (2018). Pemantau Stoping dan Infus Otomatis Dengan Sistem Telemetri Berbasis Android. E-

[3]. JPTE (Jurnal Elektronik Pendidikan Teknik Elektronika), 7(3), 210.

Candra, RA, \& Ilham, DN (2019). Analisis Efisiensi Energi Pada Aplikasi Media Sosial Menggunakan Perangkat Komunikasi Bergerak. 9, 125-131.

[3]. Candra, RA, Ilham, DN, Hardisal, H., \& Sriwahyuni, S. (2019). Perancangan Light Control Dengan Menggunakan Aplikasi Social Media Telegram Berbasis Internet Of Things (IOT). SinkrOn, 3(2), 200. https://doi.org/10.33395/sinkron.v3i2.10094

[4]. Erdisna, E. (2014). Rancang Bangun Penghitung Tetesan, Pencegah Gelembung Udara, Dan Drip Chamber Pada

Infus Pasien. MAJALAH ILMIAH UPI YPTK, 21(2).

[5]. Ilham, DN, Hardisal, H., Balkhaya, B., Candra, RA, \& Sipahutar, E. (2019). Pemantauan dan Stimulasi Detak Jantung dengan Penghafalan Alquran Berbasis Internet of Thing (IoT). SinkrOn, 4(1), 221. https://doi.org/10.33395/sinkron.v4i1.10392

[6]. Maharani, R., Muid, A., Ristian, U., Rekayasa, J., \& Komputer, S. (2019). Sistem Pemantauan Dan Peringatan Pada Volume Cairan Intravena (Infus ) Pasien Menggunakan. 07(03).

[7]. Nataliana, D., Taryana, N., \& Riandita, E. (2016). Alat Monitoring Infus Set pada Pasien Rawat Inap Berbasis

[8]. Mikrokontroler ATmega 8535. ELKOMIKA: Jurnal Teknik Energi Elektrik, Teknik Telekomunikasi, \& Teknik Elektronika, 4(1), 1.

[9]. NUR, F. (2016). Perancangan dan pembuatan alat monitoring infus pada pasien dengan menggunakan jaringan

nirkabel berbasis mikrokontroler. Universitas Muhammadiyah Malang.

[10]. Sasmoko, D., \& Wicaksono, YA (2017). Implementasi Penerapan Internet Of Things (Iot) Pada Monitoring Infus Menggunakan Esp 8266 Dan Web Untuk Berbagi Data. Jurnal Ilmiah Informatika, 2(1), 90-98.

[11]. Suprayogi, H., Priyandoko, G., Studi, P., Elektro, T., Teknik, F., Malang, UW, Studi, P., Informatika, T., Teknik,

F., \& Malang, UW (2019). Pembuatan infus elektronik rumah sakit. 5068, 23-32.

[12]. Wardani, CK, Soelistianto, FA, Taufik, M., Digital, JT, \& Malang, PN (2018). Rancang Bangun Sistem Monitoring Tetes Siklus Periodik Infus. 29-35.

[13]. Yudhana, A., \& Putra, MDD (2018). Rancang Bangun Sistem Pemantauan Infus Berbasis Android. Transmisi, 20(2), 91. https://doi.org/10.14710/transmisi.20.2.91-95

[14]. Yunardi, RT, Setiawan, D., Maulina, F., \& Prijo, TA (2018). Pengembangan Sistem Kontrol dan Pemantauan Tetesan Cairan Infus Otomatis Berbasis Labview dengan Logika Fuzzy. Jurnal Teknologi Informasi Dan Ilmu Komputer, 5(4), 403-410.

[15]. Zufa, MF (2020). Perancangan Sistem Pemantauan Level Cairan Infus Menggunakan NodeMcU dan Sensor Photodioda Terintegrasi IoT (Internet Of Thing). 